\section{G. M. Frank}

ACademician Gleb Mikhailovich FRANK, the eminent Soviet biophysicist died on October 10, 1976.

Born in 1904, Frank graduated from the University of Simferopol in 1925. From 1929 to 1943 , he worked at the Leningrad Physico-Technical Institute and then at the All-Union Institute of Experimental Medicine. From 1943-52 he carried out research in various laboratories of the Academy of Sciences of the USSR. During this time, he became increasingly associated with the Institute of Biophysics of the Academy of Sciences, becoming its Deputy Director in 1952 and Director in 1957. $\mathrm{He}$ was elected to the Academy of Sciences of the USSR in 1966.

Frank's research dealt mainly with the effect of ultraviolet light and ionising irradiation on animal organisms, and also the biophysical causes of nervous stimulation and muscular contractions. He made numerous innovations in photobiology, radiobiology and the biophysics of elementary life processes. He demonstrated the difference in the biological effects of short-wave and long-wave ultraviolet radiation, showing that, in the first case photodenaturation predominates, and in the second photolysis. His work on ultraviolet radiation found numerous applications in Soviet medical practice, including ultraviolet anaesthesia and the treatment of traumas of the peripheral nervous system.

Frank played a leading part in the development of in vivo studies of early physico-chemical and functional changes in tissues exposed to ionising radiation. He identified a number of phenomena occuring during irradiation, and developing in the latent post-irradiation period (depression, variations in the oxygen utilisation pattern, changes in the erythrocytes, and in the electrical parameters of the tissues). He also developed the concept of negative feedback in cellular processes.

In 1927, Frank published a paper showing longitudinal sections of muscle fixed at rest and during isometric contraction at various initial lengths. $\mathrm{He}$ obtained the striking result that in con- tracting muscle, the width of the $A$ bands was independent of muscle length. This was a foreshadowing of the results which in 1953-54 contributed to the establishment of the sliding-filament theory of muscle contraction. His continued interest in this area was seen when he attended the Discussion Meeting on Muscular Contraction at the Royal Society in November 1963.

His major works include Approaches to the in vivo investigation of the physico-chemical processes of nervous activity (1954). Early reactions of the organism to irradiation in dependence on local perturbations (1955), and Physico-chemical and structural principles of biological processes (1960). $\mathrm{He}$ was co-editor of the radio-biology section of the second edition of the Soviet Large Medical Encyclopaedia.

For his services to Soviet Science and Medicine, Frank was twice awarded the Order of Lenin (the highest civil award) and four times the Order of the Red Banner of Labour. His research twice received a Stalin (now State) Prize. Vera Rich

\section{Sheina Marshall}

Dr Sheina M. Marshall, OBE, FRS, died at Millport on 7 April 1977.

After holding a Carnegie Scholarship at Glasgow University, during which she showed her research abilities in a study of the behaviour and structure of Hydra, she joined the staff of the Scottish Marine Biological Association's laboratory at Millport in 1922. Here she started immediately in the field of research in which she was to be engaged for the rest of her life with the most detailed study yet made on the feeding of the copepod Calanus and a description of a new species of dinoflagellate.

She then began a remarkable collaboration with A. P. Orr, chemist on the Millport staff, through which they became known internationally as pioneers in the study of marine production. Starting with experiments on the photosynthesis of diatom cultures in bottles submerged in the sea, they proceeded to their classic investigation of the seasonal changes in nutrients and phytoplankton in Loch Striven. In this work there can be seen the seeds from which much of the modern research on productivity has developed.

They then turned their attention to the biology of Calanus and other smaller copepods which form a major constituent of the zooplankton responsible for secondary production. In part of the work on Calanus they were joined by A. G. Nicholls. A full study was made at sea of the general biology of these copepods, including their vertical distribution, successive generations throughout the year, their methods of fecding and chemical composition. This was later supplemented by experimental observation in the laboratory on respiration, food requirements, and excretion both in the adult and all young stages. By the use of radioactive phosphorus they showed its very rapid transfer to the ovaries and developing eggs and embryos, thus confirming their theory that abundant food is necessary for egg laying resulting in an adaptation whereby the hatching of the nauplii coincides with diatom outbursts.

After the death of Orr in 1962 Sheina Marshall started further collaboration with E. D. S. Corner, biochemist at the Plymouth laboratory of the Marine Biological Association. Thus her remarkable expertise and knowledge of copepod biology has been made available to a new generation of workers in the field of marine production. Her last investigation was concerned with the overwintering generation of Calanus in which it was shown that a partially carnivorous diet is probably necessary for survival.

In 1928 Marshall and Orr went with the Great Barrier Reef Expedition to Australia. There they undertook a similar seasonal investigation to that made in Loch Striven on the nutrient and phytoplankton cycles in the reef area. This was the first to be done on this scale in tropical waters. Sheina, always indefatigable, made observations also on the occurrence of symbiotic algae in coral planulae, and with Orr investigated the ability of certain corals to rid themselves of silt.

On their return to Millport they made a short investigation, with $\mathrm{A}$. G. Nicholls, on the growth of the early stages of the herring in the Clyde Sea Area, which is probably the most complete observation made on a single brood.

During the war she was engaged on two projects in the applied field, namely the fertilisation of sea lochs and the production of agar from the seaweed Gigartina.

Although not a systematist she had a special interest in tintinnids on which she wrote a Barrier Reef report and prepared plankton identification sheets for the International Council for the Exploration of the Sea.

Her work with Orr was brought together in their book The Biology of a Copepod, and she amplified and prepared for press Orr's Buckland lectures given in 1957 to form the book The Fertile Sea.

Much travelled, her loss will be felt by many friends all over the world who got to know her sterling qualities.

F. S. Russell 